Journal homepage: www.aesacademy.org

\title{
Influence of sowing date on the growth and yield performance of wheat (Triticum aestivum L.) varieties
}

\author{
Utpal Madhu, Mahfuza Begum, Abdus Salam and Shubroto Kumar Sarkar*
}

Department of Agronomy, Bangladesh Agricultural University, Mymensingh 2202, BANGLADESH

"Corresponding author's E-mail: shubroto.252@gmail.com

\section{ARTICLE HISTORY}

Received: 18 February 2018

Revised received: 25 February 2018

Accepted: 28 February 2018

\section{Keywords}

BARI Gom

Growth and yield performance

Harvest index

Sowing date

Wheat

\section{ABSTRACT}

A field study was conducted at the Agronomy Field Laboratory, Bangladesh Agricultural University, Mymensingh to investigate the effect of sowing date on the performance of wheat varieties. The experiment, laid out in RCBD with three replications, comprised four sowing dates viz.,15 November, 30 November, 15 December and 30 December, and four varieties of wheat viz. BARI Gom 25, BARI Gom 26, BARI Gom 27 and Shatabdi. The results suggested that the highest plant population $\mathrm{m}^{-2}(58.17)$ and the highest plant height $(89.59 \mathrm{~cm})$ were obtained in 15 November sowing. BARI Gom 25 produced the highest plant population $\mathrm{m}^{-2}$ (50.33) and the highest plant height (86.32) while the same trend was observed in the interaction of BARI Gom $25 \times 15$ November sowing. The lowest performance of these two parameters was observed in the interaction of Shatabdi $\times 30$ December sowing. The highest grain yield $\left(2.18 \mathrm{ha}^{-1}\right)$ was found in the interaction of BARI Gom $25 \times 15$ November sowing as contributed by its highest number of effective tillers hill $^{-1}(4.73)$, the highest number of spikelets spike ${ }^{-1}$ (17.77), the highest number of grains spike ${ }^{-1}$ (37.89) and the highest 1000-grain weight $(29.99 \mathrm{~g})$. The individual effect of the BARI Gom 25 and 15 November sowing on those parameters was also observed as the highest. The lowest grain yield $\left(1.5 \mathrm{tha}^{-1}\right)$ was found in the interaction of Shatabdi $\times 30$ December sowing because of the poor performance of the yield components of this treatment combination. The variety BARI Gom 25 and BARI Gom 26 both gave better yield when sown on 15 November. Therefore, BARI Gom 25 and BARI Gom 26 should be sown on 15 November rather than late sowing to obtain better performance and grain yield of wheat.

(C)2018 Agriculture and Environmental Science Academy

Citation of this article: Madhu, U., Begum, M., Salam, A. and Sarkar, S.K. (2018). Influence of sowing date on the growth and yield performance of wheat (Triticum aestivum L.) varieties. Archives of Agriculture and Environmental Science, 3(1) 89-94 DOI: 10.26832/24566632.2018.0301014

\section{INTRODUCTION}

Wheat (Triticum aestivum L.) holds the second position among the cereal crops in Bangladesh. With the introduction of high yielding varieties, the area and production of wheat has been increased substantially. In recent time, wheat had gained much popularity among the farmers of Bangladesh due to its lower cost of production than that of rice (Boro rice) grown in the same season. The annual production of wheat in 2012-2013 was 12.55 lakh tons obtained from 4.16 lakh hectares of land with an average yield of $3.01 \mathrm{t} \mathrm{ha}^{-1}$ (BBS, 2013). Among the production factors, sowing time is the most important factors deciding its productivity. Zia-ul-Hassan et al. (2014) observed that Wheat yield is far below than the potential yield due to many factors of which sowing time being most important. Generally the time of sowing of wheat varies with the climate of the region and the variety used. The duration of growing period of wheat is narrow. Therefore, date of sowing is the most crucial factor affecting the growth and yield of this crop to a great extent. Saini et al. (1986) reported that with rise of $1^{\circ} \mathrm{C}$ temperature above the optimum level during grain filling stage, the grain weight decreased by about $232.56 \mathrm{mg}$ plant $^{-1}$ day $^{-1}$. Variety is another important factor playing a crucial role in producing high yield of wheat. Different varieties respond differently for their genotypic char- 
acters, input requirement, growth process and the prevailing environment during growing season (Sultana et al., 2012). The growth process of wheat plants under a given agro-climatic condition differs with variety (Anonymous, 1990). In addition, identification of variety with specific date of sowing is essential for better yield of the crop. Hence, the purpose of the present field study was to investigate the response of new high yielding wheat varieties released by BARI against varying sowing times.

\section{MATERIALS AND METHODS}

The experiment was conducted at the Agronomy Field Laboratory, Bangladesh Agricultural University, Mymensingh. The soil of experimental land is loamy in texture with moderately acidic in nature having $\mathrm{pH}$ 6.8. The experiment was laid out in a Randomized Complete Block Design (RCBD) with three replications. The experimental treatments included i) four Sowing dates, 15 November $\left(S_{1}\right)$, 30 November $\left(S_{2}\right)$, 15 December $\left(S_{3}\right)$ and 30 December $\left(\mathrm{S}_{4}\right)$ and ii) four wheat varieties viz. BARI Gom $25\left(V_{1}\right)$, BARI Gom $26\left(V_{2}\right)$, BARI Gom $27\left(V_{3}\right)$ and Shatabdi $\left(V_{4}\right)$. There were 48 plots each of $4 \mathrm{~m} \times 2.5 \mathrm{~m}$ i.e. $10 \mathrm{~m}^{2}$. After land preparation, the field was uniformly fertilized with $220 \mathrm{~kg}$ urea, $160 \mathrm{~kg}$ triple super phosphate (TSP), $100 \mathrm{~kg}$ murate of potash (MoP) and $110 \mathrm{~kg}$ gypsum ha ${ }^{-1}$, respectively. One-half of urea and entire amount of other fertilizers were applied basally at the time of final land preparation and the remaining $1 / 2$ portion of urea was top dressed at crown root initiation stage. Seeds were collected from Bangladesh Agricultural Research Institute (BARI), Joydebpur, Gazipur and were sown @120 kg seeds ha-1 at four different sowing dates as stated in the treatment. Care was taken to protect the seedlings from birds upto 12 days after sowing. The experimental plots were irrigated three times. First irrigation was given at crown root initiation stage (17-21 days after sowing), the second one at early booting stage (45-50 days after sowing) and finally, third one was given during grain formation (75-80 days after sowing).

Growth study was continued from 7 days after sowing (DAS) to 60 DAS. Five plants samples plot $^{-1}$ were selected randomly for taking data on yield components. The crop was harvested from $1 \mathrm{~m}^{2}$ at full maturity i.e.; after $80 \%$ maturity of the crops of each plot. The harvested crop was bundled separately from each plot then tagged and taken to the harvesting floor. The grains were separated from straw and were sun dried carefully for 4-6 days up to $14 \%$ moisture content. Finally, grain and straw yields per plot were recorded and converted to $\mathrm{t} \mathrm{ha}^{-1}$. Grain yield at $14 \%$ moisture content was calculated by using the following formula:

Grain yield at $14 \%$ moisture content $=\{(100-$ Sample moisture content) / 86 $\} \times$ Weight of grains at sample moisture content.

Data recorded for different parameters were compiled and tabulated in proper form for statistical analysis. The recorded data on various plant characters were statistically analyzed using of MSTAT and mean difference among the treatments were adjudged with Duncan's Multiple Range Test (DMRT) as described by Gomez and Gomez (1984).

\section{RESULTS AND DISCUSSION}

\section{Effect of sowing date}

The effect of sowing date on all the crop parameters studied in this experiment was significant (Tables 1, 2). Among the four sowing dates, 15 November sowing gave the better performance in most of the growth and yield parameters. The highest plant population $\mathrm{m}^{-2}$ (58.17) was found on 15 November sowing followed by decreasing trend at the later sowing dates reaching the lowest plant population $\mathrm{m}^{-2}$ (36.92) on sowing in 30 December (Table 1). There was an increasing trend of plant height for all the sowing dates from 30 DAS up to harvesting. The highest plant height was obtained in 15 November sowing for all the recorded date of sowing up to harvest whereas, the lowest plant height was found in 30 December (Table 1).

The results showed that the highest number of total tillers hill ${ }^{-1}$ (4.89), the highest number of effective tillers hill $^{-1}$ (4.15), the highest number of total spikelets spike ${ }^{-1}(15.68)$, the lowest number of non-effective spikelets spike ${ }^{-1}$ (1.64), the highest spike length $(10.13 \mathrm{~cm})$, the highest number of grains spike ${ }^{-1}$ (35.43), the lowest number of sterile grains spike ${ }^{-1}$ (1.39) and the highest 1000 -grain weight $(27.47 \mathrm{~g})$ were found on 15 November sowing. The highest wheat grain yield $\left(2.00 \mathrm{t} \mathrm{ha}^{-1}\right)$, the highest straw yield (5.22 $\left.\mathrm{t} \mathrm{ha}^{-1}\right)$ and the highest biological yield (7.23 $\mathrm{t} \mathrm{ha}^{-1}$ ) were also found on 15 November sowing (Table 2). The highest harvest index (31.66\%) was recorded in 30 December sowing and the lowest (27.70\%) was found in 15 November sowing. In fact, the highest performance of the yield components of wheat in 15 November sowing resulted in the highest yield in the same sowing date. On the other hand, the lowest grain yield $\left(1.58 \mathrm{t} \mathrm{ha}^{-1}\right)$ was found in 30 December sowing because of the lowest performance of the yield contributing characters. Date of sowing on 30 November and 15 December showed the intermediate performance producing grain yield of 1.76 and $1.64 \mathrm{t} \mathrm{ha}^{-1}$ (Table 2). The yield reduction due to delay in sowing might be due to reduction in spikes plant ${ }^{-1}$, spikelets spike $^{-1}$, grains spike ${ }^{-1}$ and 1000-grain weight. Akhtar et al. (2006) and Shah et al. (2006) found that the number of effective tillers reduces by delayed sowing. The result of the present investigation is in close conformity with that of BARI (1990) which reported yield reduction due to delay in sowing due to reduction in number of spikes $\mathrm{m}^{-2}$, grains spike ${ }^{-1}$ and 1000 -grain weight. Similar results were also obtained by Hossain and Alam (1986).

\section{Effect of variety}

The varietal differences exerted a significant effect on all the crop and yield characters (Tables 1,3 ). The wheat variety BARI Gom 25 produced the highest number of plant population $\mathrm{m}^{-2}$ (50.33) and the lowest plant population $\mathrm{m}^{-2}$ (38.75) was found in the variety Shatabdi (Table 1). BARI Gom 25 also gave the highest plant heights at 30,45,60 DAS and upto harvest and the lowest plant heights were found in variety Shatabdi for all the 
recorded dates upto harvest. It was observed that plant height increased with increasing the age of the plant (Table 1). The highest number of total tillers hill $^{-1}$ (4.65), the highest number of effective tillers hill $^{-1}$ (3.84), the highest number of total spikelets spike $^{-1}$ (15.63), the highest length of spike $(9.99 \mathrm{~cm})$, the highest grains spike $^{-1}$ (33.62), the highest 1000 -grain weight (27.35) but the lowest number of grains spike ${ }^{-1}(1.56)$ and the lowest number of non-effective spikelets spike ${ }^{-1}$ (1.88) were found in BARI Gom 25 (Table 3). The highest grain yield $\left(1.85 \mathrm{t} \mathrm{ha}^{-1}\right)$ was found in variety BARI Gom 25 , which was statistically similar to that of BARI Gom 26 (1.81 $\left.\mathrm{t} \mathrm{ha}^{-1}\right)$. The lowest grain yield was recorded in variety Shatabdi (1.63 t ha ${ }^{-1}$ ). BARI Gom 27 produced intermediate (1.69 $\mathrm{t} \mathrm{ha}^{-1}$ ) yield (Table 3). The highest straw yield (4.84 t ha$\left.{ }^{1}\right)$ and the highest biological yield $\left(6.70 \mathrm{tha}^{-1}\right)$ were found in BARI Gom 25 but the highest harvest index (30.27\%) was recorded on variety BARI Gom 26 (Table 3). Differences of grain yields among the varieties might be due to the inherent quality of varieties. Vaishya and Singh (1981) reported that varietal differences exhibit significant effect in the grain yield of wheat.

Interaction effect of sowing date and variety

The effect of interaction between variety and date of sowing on the growth and yield parameters of wheat was significant (Tables 1, 4). The highest plant population $\mathrm{m}^{-2}$ (65.67) was obtained from the interaction between variety BARI Gom 25 and 15 November sowing followed by BARI Gom $26 \times 15$ November sowing, BARI Gom $27 \times 15$ November sowing and BARI Gom $27 \times 30$ November sowing while the lowest plant population $\mathrm{m}^{-2}$ (31.00) was found from the interaction of variety Shatabdi $\times 30$ December sowing (Table 1 ). The highest plant heights at 30, 45, 60 DAS and at harvest were recorded in the interaction of BARI Gom $25 \times 15$ November sowing. The lowest plant height at 30, 45, 60 DAS and at harvest were obtained from the interaction of variety Shatabdi $\times 30$ December sowing
(Table 1). Rahman et al. (2015) stated that initial plant population, spikes $\mathrm{m}^{-2}$ and grain yield of wheat were significantly influenced by the interaction of sowing time and variety. The highest number of total tillers hill ${ }^{-1}$ (5.40), the highest number of effective tillers hill $^{-1}$ (4.73), the highest number of total spikelets spike $^{-1}(17.77)$, the highest spike length $(10.79 \mathrm{~cm})$, the highest (37.89) number of grains spike ${ }^{-1}$, the highest 1000-grain weight (29.99 g), and the lowest number of non-effective spikelets spike $^{-1}$ (1.33) and the lowest number of sterile grains spike ${ }^{-1}$ (1.15) were found in the interaction of variety BARI Gom $25 \times$ 15 November sowing (Table 4, 5, 6). As the performance of the crop characters as well as the yield contributing characters was found superior in BARI Gom $25 \times 15$ November sowing, it resulted in the highest grain yield of $2.18 \mathrm{t} \mathrm{ha}^{-1}$. Similar findings were also produced by Aslam et al. (2003), Bajwa et al. (1987) and Chaudhry et al. (1992).

The second highest grain yield of $2.07 \mathrm{t} \mathrm{ha}^{-1}$ was found in the interaction of BARI Gom $26 \times 15$ November sowing. The lowest grain yield of $1.50 \mathrm{t} \mathrm{ha}^{-1}$ was observed in the interaction of Shatabdi $\times 30$ December sowing because of the lowest number of effective tillers hill ${ }^{-1}$ (1.83), the lowest number of grains spike ${ }^{-1}$ (26.42) and the lowest (22.63g) 1000-grain weight (Table 4). Rahman et al. (2015) also found that the yield of Shatabdi was significantly declined due to late sowing on December 10 as compared to sowing on November 20. The highest biological yield $\left(7.72 \mathrm{t} \mathrm{ha}^{-1}\right)$ was obtained from the interaction of BARI Gom $25 \times 15$ November sowing and the lowest biological yield $\left(4.67 \mathrm{t} \mathrm{ha}^{-1}\right)$ was obtained from the interaction of Shatabdi $\times 30$ December sowing. The highest harvest index (33.68\%) was obtained from the interaction of BARI Gom $27 \times 30$ December sowing which was statistically identical to the harvest index (33.23\%) found from the interaction of BARI Gom $26 \times 30$ December. The lowest harvest index (26.74\%) was found in the interaction of BARI Gom 27 × 15 November sowing (Table 4).

Table 1. Effect of sowing date on plant population and plant height at different days after sowing.

\begin{tabular}{lccccc}
\hline \multirow{2}{*}{ Treatments } & \multirow{2}{*}{ Plant population $\left(\mathrm{m}^{-2}\right)$} & \multicolumn{3}{c}{ Plant height $(\mathrm{cm})$} \\
\cline { 3 - 6 } & & 30DAS & 45DAS & 60DAS & Harvest \\
\hline 15 November & $58.17 \mathrm{a}$ & $27.17 \mathrm{a}$ & $45.67 \mathrm{a}$ & $67.83 \mathrm{a}$ & $89.59 \mathrm{a}$ \\
30 November & $46.92 \mathrm{~b}$ & $24.33 \mathrm{~b}$ & $44.00 \mathrm{~b}$ & $63.42 \mathrm{~b}$ & $82.82 \mathrm{~b}$ \\
15 December & $39.67 \mathrm{c}$ & $22.77 \mathrm{c}$ & $37.17 \mathrm{c}$ & $59.17 \mathrm{c}$ & $79.75 \mathrm{c}$ \\
30 December & $36.92 \mathrm{~d}$ & $20.08 \mathrm{~d}$ & $33.58 \mathrm{~d}$ & $52.17 \mathrm{~d}$ & $71.49 \mathrm{~d}$ \\
Sig. level & $* *$ & ${ }^{* *}$ & ${ }^{* *}$ & 3.22 & \\
CV $(\%)$ & 1.38 & 3.02 & 1.71 & & 0.92 \\
\hline
\end{tabular}

Table 2. Effect of sowing date on yield and yield attributes of wheat.

\begin{tabular}{|c|c|c|c|c|c|c|c|c|c|c|c|c|}
\hline Treatments & $\begin{array}{c}\text { No. of } \\
\text { total } \\
\text { tillers } \\
\text { hill }^{-1}\end{array}$ & $\begin{array}{c}\text { No. of } \\
\text { effective } \\
\text { tillers } \\
\text { hill }^{-1}\end{array}$ & $\begin{array}{l}\text { No. of } \\
\text { total } \\
\text { spikelets } \\
\text { spike }^{-1}\end{array}$ & $\begin{array}{c}\text { No. of } \\
\text { non- } \\
\text { effective } \\
\text { spikelets } \\
\text { spike }^{-1}\end{array}$ & $\begin{array}{l}\text { Spike } \\
\text { length } \\
(\mathrm{cm})\end{array}$ & $\begin{array}{l}\text { No. of } \\
\text { grains } \\
\text { spike }^{-1}\end{array}$ & $\begin{array}{l}\text { No. of } \\
\text { sterile } \\
\text { grains } \\
\text { spike }^{-1}\end{array}$ & $\begin{array}{l}\text { Weight } \\
\text { of } 1000 \\
\text {-grain } \\
\text { (g) }\end{array}$ & $\begin{array}{l}\text { Grain } \\
\text { yield } \\
\left(\mathrm{t} \mathrm{ha}^{-1}\right)\end{array}$ & $\begin{array}{l}\text { Straw } \\
\text { yield } \\
\left(\mathrm{t} \mathrm{ha}^{-1}\right)\end{array}$ & $\begin{array}{c}\text { Biological } \\
\text { yield } \\
\left(\mathrm{t} \mathrm{ha}^{-1}\right)\end{array}$ & $\begin{array}{c}\text { Harvest } \\
\text { index } \\
(\%)\end{array}$ \\
\hline $\begin{array}{l}15 \\
\text { November }\end{array}$ & $4.89 a$ & $4.15 a$ & $15.68 \mathrm{a}$ & $1.64 \mathrm{~d}$ & $10.13 a$ & $35.43 a$ & $1.39 c$ & $27.47 a$ & $2.00 \mathrm{a}$ & $5.22 \mathrm{a}$ & $7.23 a$ & $27.70 \mathrm{~d}$ \\
\hline $\begin{array}{l}30 \\
\text { November }\end{array}$ & $4.47 b$ & $3.57 b$ & $14.74 b$ & $1.97 c$ & $9.67 b$ & $33.17 b$ & $1.64 \mathrm{~b}$ & $26.11 b$ & $1.76 \mathrm{~b}$ & $4.42 \mathrm{~b}$ & $6.19 \mathrm{~b}$ & $28.54 \mathrm{c}$ \\
\hline $\begin{array}{l}15 \\
\text { December }\end{array}$ & $3.99 c$ & $2.99 c$ & $13.23 c$ & $2.31 b$ & $9.29 c$ & $31.24 c$ & $1.74 b$ & $24.73 c$ & $1.64 c$ & $3.94 c$ & $5.59 c$ & $29.47 b$ \\
\hline $\begin{array}{l}30 \\
\text { December }\end{array}$ & $3.48 d$ & $2.38 d$ & $12.25 d$ & $2.64 a$ & $8.38 \mathrm{~d}$ & $27.76 d$ & $2.10 a$ & $23.87 d$ & $1.58 \mathrm{~d}$ & $3.41 \mathrm{~d}$ & $4.99 d$ & $31.66 a$ \\
\hline Sig. level & $* *$ & $* *$ & $* *$ & ** & $* *$ & ** & $* *$ & $* *$ & ** & $* *$ & $* *$ & $* *$ \\
\hline CV (\%) & 0.8 & 1.08 & 0.74 & 1.5 & 1.08 & 2.01 & 7.45 & 1.83 & 2.27 & 1.1 & 0.88 & 2.19 \\
\hline
\end{tabular}


Table 3. Effect of variety on plant population and plant height at different days after sowing.

\begin{tabular}{|c|c|c|c|c|c|}
\hline \multirow{2}{*}{ Treatments } & \multirow{2}{*}{ Plant population $\left(\mathrm{m}^{-2}\right)$} & \multicolumn{4}{|c|}{ Plant height (cm) } \\
\hline & & 30 DAS & 30 DAS & 30 DAS & $30 \mathrm{DAS}$ \\
\hline BARI Gom 25 & $50.33 a$ & $26.00 \mathrm{a}$ & $43.08 a$ & $64.08 \mathrm{a}$ & $86.32 \mathrm{a}$ \\
\hline BARI Gom 26 & $48.25 b$ & $23.67 b$ & $41.67 b$ & $62.25 \mathrm{~b}$ & $81.15 b$ \\
\hline BARI Gom 27 & $44.33 c$ & $23.00 c$ & $39.25 c$ & $58.50 c$ & $78.95 c$ \\
\hline Shatabdi & $38.75 d$ & $21.69 \mathrm{~d}$ & $36.42 \mathrm{~d}$ & $57.75 c$ & $77.23 d$ \\
\hline Sig. level & $* *$ & $* *$ & $* *$ & $* *$ & $* *$ \\
\hline CV (\%) & 1.38 & 3.02 & 1.71 & 3.22 & 0.92 \\
\hline
\end{tabular}

Table 4. Effect of variety on yield and yield attributes of wheat.

\begin{tabular}{|c|c|c|c|c|c|c|c|c|c|c|c|c|}
\hline Varieties & $\begin{array}{c}\text { No. of } \\
\text { total } \\
\text { tillers } \\
\text { hill }^{-1}\end{array}$ & $\begin{array}{l}\text { No. of } \\
\text { effective } \\
\text { tillers } \\
\text { hill }^{-1}\end{array}$ & $\begin{array}{c}\text { No. of } \\
\text { total } \\
\text { spikelets } \\
\text { spike }^{-1}\end{array}$ & $\begin{array}{c}\text { No. of } \\
\text { non- } \\
\text { effective } \\
\text { spikelets } \\
\text { spike }^{-1}\end{array}$ & $\begin{array}{c}\text { Spike } \\
\text { length } \\
(\mathrm{cm})\end{array}$ & $\begin{array}{l}\text { No. of } \\
\text { grains } \\
\text { spike }^{-1}\end{array}$ & $\begin{array}{l}\text { No. of } \\
\text { sterile } \\
\text { grains } \\
\text { spike }^{-1}\end{array}$ & $\begin{array}{l}\text { Weight } \\
\text { of } 1000 \\
\text {-grain } \\
\text { (g) }\end{array}$ & $\begin{array}{c}\text { Grain } \\
\text { yield } \\
\left(\mathrm{t} \mathrm{ha}^{-1}\right)\end{array}$ & $\begin{array}{c}\text { Straw } \\
\text { yield } \\
\left(\mathrm{t} \mathrm{ha}^{-1}\right)\end{array}$ & $\begin{array}{c}\text { Biological } \\
\text { yield } \\
\left(\mathrm{t} \mathrm{ha}^{-1}\right)\end{array}$ & $\begin{array}{c}\text { Harvest } \\
\text { index } \\
(\%)\end{array}$ \\
\hline $\begin{array}{l}\text { BARI } \\
\text { Gom- } 25\end{array}$ & $4.65 a$ & $3.84 a$ & $15.63 a$ & $1.88 \mathrm{~d}$ & $9.99 a$ & $33.62 \mathrm{a}$ & $1.56 \mathrm{c}$ & $27.35 a$ & $1.85 a$ & $4.84 a$ & $6.70 \mathrm{a}$ & $27.69 c$ \\
\hline $\begin{array}{l}\text { BARI } \\
\text { Gom- } 26\end{array}$ & $4.33 b$ & $3.46 b$ & $13.68 b$ & $2.09 c$ & $9.54 b$ & $32.58 b$ & $1.62 \mathrm{c}$ & $25.55 b$ & $1.81 a$ & $4.17 b$ & $5.99 \mathrm{~b}$ & $30.27 a$ \\
\hline $\begin{array}{l}\text { BARI } \\
\text { Gom- } 27\end{array}$ & $4.13 c$ & $3.18 c$ & $13.28 c$ & $2.20 \mathrm{~b}$ & $8.98 c$ & $31.35 c$ & $1.76 \mathrm{~b}$ & $24.99 c$ & $1.69 \mathrm{~b}$ & $4.07 c$ & $5.77 c$ & $29.31 b$ \\
\hline Shatabdi & $3.74 \mathrm{~d}$ & $2.61 \mathrm{~d}$ & $13.32 \mathrm{c}$ & $2.39 a$ & $8.94 c$ & $30.05 d$ & $1.93 a$ & $24.28 d$ & $1.63 c$ & $3.91 d$ & $5.55 \mathrm{~d}$ & $29.53 b$ \\
\hline Sig. level & $* *$ & $* *$ & $* *$ & $* *$ & $* *$ & $* *$ & $* *$ & $* *$ & $* *$ & $* *$ & $* *$ & $* *$ \\
\hline CV (\%) & 0.8 & 1.08 & 0.74 & 1.5 & 1.08 & 2.01 & 7.45 & 1.83 & 2.27 & 1.1 & 0.88 & 2.19 \\
\hline
\end{tabular}

Table 5. Interaction effect of variety and sowing date on plant population and plant height at different days after sowing.

\begin{tabular}{|c|c|c|c|c|c|}
\hline \multirow{2}{*}{ Treatments } & \multirow{2}{*}{ Plant population $\left(\mathrm{m}^{-2}\right)$} & \multicolumn{4}{|c|}{ Plant height $(\mathrm{cm})$} \\
\hline & & 30 DAS & 30 DAS & 30 DAS & 30 DAS \\
\hline $\mathrm{V}_{1} \mathrm{~S}_{1}$ & $65.67 a$ & $29.33 a$ & $47.33 \mathrm{a}$ & $70.00 \mathrm{a}$ & $95.57 a$ \\
\hline $\mathrm{V}_{1} \mathrm{~S}_{2}$ & $47.33 \mathrm{fg}$ & $26.33 b c$ & $46.67 a$ & $64.34 b-d$ & $87.08 c$ \\
\hline $\mathrm{V}_{1} \mathrm{~S}_{3}$ & $46.33 \mathrm{~g}$ & $24.33 d$ & $40.00 \mathrm{e}$ & $64.00 \mathrm{~b}-\mathrm{d}$ & $85.67 d$ \\
\hline $\mathrm{V}_{1} \mathrm{~S}_{4}$ & $42.00 \mathrm{~h}$ & $24.00 \mathrm{~d}$ & $38.33 f$ & 58.00 ef & $76.95 \mathrm{gh}$ \\
\hline $\mathrm{V}_{2} \mathrm{~S}_{1}$ & $63.00 \mathrm{~b}$ & $27.00 \mathrm{~b}$ & $47.00 \mathrm{a}$ & $69.67 \mathrm{a}$ & $90.66 \mathrm{~b}$ \\
\hline $\mathrm{V}_{2} \mathrm{~S}_{2}$ & $47.67 f$ & $24.33 d$ & $44.00 \mathrm{c}$ & $66.67 \mathrm{ab}$ & $82.21 \mathrm{e}$ \\
\hline $\mathrm{V}_{2} \mathrm{~S}_{3}$ & $41.67 \mathrm{hi}$ & $23.33 \mathrm{de}$ & $40.67 \mathrm{de}$ & $57.00 \mathrm{f}$ & $79.47 f$ \\
\hline $\mathrm{V}_{2} \mathrm{~S}_{4}$ & $40.67 \mathrm{ij}$ & $20.00 \mathrm{fg}$ & $35.00 \mathrm{~g}$ & $55.67 f$ & $72.27 i$ \\
\hline $\mathrm{V}_{3} \mathrm{~S}_{1}$ & $53.67 \mathrm{c}$ & $26.67 b c$ & $45.33 b$ & $67.00 \mathrm{ab}$ & $86.64 \mathrm{~cd}$ \\
\hline $\mathrm{V}_{3} \mathrm{~S}_{2}$ & $52.33 d$ & $24.00 d$ & $44.00 \mathrm{c}$ & $61.00 \mathrm{de}$ & $81.87 \mathrm{e}$ \\
\hline $\mathrm{V}_{3} \mathrm{~S}_{3}$ & $37.33 \mathrm{k}$ & 22.33 e & $36.00 \mathrm{~g}$ & 58.00 ef & $77.75 \mathrm{~g}$ \\
\hline $\mathrm{V}_{3} \mathrm{~S}_{4}$ & $34.00 \mathrm{i}$ & $19.00 \mathrm{~g}$ & $31.67 \mathrm{~h}$ & $48.00 \mathrm{~g}$ & $69.54 j$ \\
\hline $\mathrm{V}_{4} \mathrm{~S}_{1}$ & $50.33 \mathrm{e}$ & $25.67 c$ & $43.00 \mathrm{c}$ & $64.67 \mathrm{bc}$ & $85.49 d$ \\
\hline $\mathrm{V}_{4} \mathrm{~S}_{2}$ & $40.33 j$ & $22.67 \mathrm{e}$ & $41.33 d$ & $61.67 \mathrm{~cd}$ & $80.12 f$ \\
\hline $\mathrm{V}_{4} \mathrm{~S}_{3}$ & $33.33 i$ & $21.11 \mathrm{f}$ & $32.00 \mathrm{~h}$ & $57.67 \mathrm{ef}$ & $76.13 \mathrm{~h}$ \\
\hline $\mathrm{V}_{4} \mathrm{~S}_{4}$ & $31.00 \mathrm{~m}$ & $17.33 \mathrm{~h}$ & $29.33 \mathrm{i}$ & $47.00 \mathrm{~g}$ & $67.18 \mathrm{k}$ \\
\hline Sig. level & $* *$ & $* *$ & $* *$ & $* *$ & $* *$ \\
\hline CV (\%) & 1.38 & 3.02 & 1.71 & 3.22 & 0.92 \\
\hline
\end{tabular}


Table 6. Interaction effect of sowing date and variety on yield and yield attributes of wheat.

\begin{tabular}{|c|c|c|c|c|c|c|c|c|c|c|c|c|}
\hline $\begin{array}{l}\text { Treatment } \\
\text { combinations }\end{array}$ & $\begin{array}{c}\text { No. of } \\
\text { total } \\
\text { tillers } \\
\text { hill }^{-1}\end{array}$ & $\begin{array}{c}\text { No. of } \\
\text { effective } \\
\text { tillers } \\
\text { hill }^{-1}\end{array}$ & $\begin{array}{l}\text { No. of } \\
\text { total } \\
\text { spikelets } \\
\text { spike }^{-1}\end{array}$ & $\begin{array}{c}\text { No. of non } \\
\text {-effective } \\
\text { spikelets } \\
\text { spike }^{-1}\end{array}$ & $\begin{array}{l}\text { Spike } \\
\text { length } \\
\text { (cm) }\end{array}$ & $\begin{array}{l}\text { No. of } \\
\text { grains } \\
\text { spike }^{-1}\end{array}$ & $\begin{array}{l}\text { No. of } \\
\text { sterile } \\
\text { grains } \\
\text { spike }^{-1}\end{array}$ & $\begin{array}{l}\text { Weight } \\
\text { of } 1000- \\
\text { grain (g) }\end{array}$ & $\begin{array}{c}\text { Grain } \\
\text { yield } \\
\left(\mathrm{tha}^{-1}\right)\end{array}$ & $\begin{array}{c}\text { Straw } \\
\text { yield } \\
\left(\mathrm{t} \mathrm{ha}^{-1}\right)\end{array}$ & $\begin{array}{c}\text { Biological } \\
\text { yield } \\
\left(\mathrm{tha}^{-1}\right)\end{array}$ & $\begin{array}{c}\text { Harvest } \\
\text { index } \\
(\%)\end{array}$ \\
\hline $\mathrm{V}_{1} \mathrm{~S}_{1}$ & $5.40 \mathrm{a}$ & $4.73 a$ & $17.77 a$ & $1.33 \mathrm{k}$ & $10.79 a$ & $37.89 a$ & $1.15 \mathrm{i}$ & $29.99 a$ & $2.18 a$ & $5.53 \mathrm{a}$ & $7.72 \mathrm{a}$ & 28.32 ef \\
\hline $\mathrm{V}_{1} \mathrm{~S}_{2}$ & $5.00 \mathrm{~b}$ & $4.25 b$ & $16.60 \mathrm{~b}$ & $1.75 \mathrm{i}$ & $10.53 b$ & $34.08 \mathrm{~cd}$ & $1.56 \mathrm{fg}$ & $27.73 b$ & $1.89 \mathrm{c}$ & $5.10 \mathrm{~b}$ & $6.99 c$ & $27.03 \mathrm{gh}$ \\
\hline $\mathrm{V}_{1} \mathrm{~S}_{3}$ & $4.40 \mathrm{e}$ & $3.53 \mathrm{e}$ & $14.47 f$ & 2.10 ef & $9.88 \mathrm{~d}$ & $33.21 \mathrm{~d}-\mathrm{f}$ & $1.60 \mathrm{e}-\mathrm{g}$ & $26.38 \mathrm{de}$ & $1.74 \mathrm{~d}$ & $4.67 d$ & $6.42 \mathrm{e}$ & $27.22 \mathrm{f}-\mathrm{h}$ \\
\hline $\mathrm{V}_{1} \mathrm{~S}_{4}$ & $3.80 \mathrm{j}$ & $2.85 \mathrm{i}$ & $13.67 \mathrm{~h}$ & $2.33 c$ & $8.78 \mathrm{~h}$ & $29.29 \mathrm{i}$ & $1.93 \mathrm{~cd}$ & $25.29 \mathrm{gh}$ & $1.60 \mathrm{f}-\mathrm{h}$ & $4.07 f$ & $5.67 \mathrm{~h}$ & $28.21 \mathrm{e}-\mathrm{g}$ \\
\hline $\mathrm{V}_{2} \mathrm{~S}_{1}$ & $5.00 \mathrm{~b}$ & $4.30 \mathrm{~b}$ & $15.20 c$ & $1.66 \mathrm{j}$ & $10.33 c$ & $35.77 b$ & $1.31 \mathrm{hi}$ & $27.30 \mathrm{bc}$ & $2.07 b$ & $5.47 a$ & $7.54 b$ & $27.48 \mathrm{f}-\mathrm{h}$ \\
\hline$V_{2} S_{2}$ & $4.66 \mathrm{~d}$ & $3.81 \mathrm{~d}$ & $14.36 \mathrm{f}$ & $1.90 \mathrm{~g}$ & $9.76 \mathrm{~d}$ & $34.34 \mathrm{~cd}$ & $1.54 \mathrm{fg}$ & $26.14 d-f$ & $1.86 \mathrm{c}$ & $4.37 e$ & $6.23 f$ & $29.85 \mathrm{~cd}$ \\
\hline $\mathrm{V}_{2} \mathrm{~S}_{3}$ & $4.00 \mathrm{~h}$ & $3.10 \mathrm{~g}$ & $13.03 i$ & $2.13 \mathrm{de}$ & $9.52 \mathrm{e}$ & $32.11 \mathrm{fg}$ & $1.64 \mathrm{e}-\mathrm{g}$ & $24.74 \mathrm{hi}$ & $1.67 \mathrm{~d}-\mathrm{f}$ & $3.56 \mathrm{i}$ & $5.24 \mathrm{k}$ & $32.02 b$ \\
\hline $\mathrm{V}_{2} \mathrm{~S}_{4}$ & $3.66 \mathrm{k}$ & $2.66 \mathrm{j}$ & $12.12 \mathrm{k}$ & $2.66 \mathrm{~b}$ & $8.57 i$ & $28.10 \mathrm{jk}$ & $1.99 b c$ & $24.03 \mathrm{ij}$ & $1.64 \mathrm{e}-\mathrm{g}$ & $3.30 \mathrm{j}$ & $4.94 \mathrm{i}$ & $33.23 a$ \\
\hline $\mathrm{V}_{3} \mathrm{~S}_{1}$ & $4.93 c$ & $4.18 c$ & $15.00 \mathrm{~d}$ & $1.75 \mathrm{i}$ & $9.90 \mathrm{~d}$ & $34.78 \mathrm{bc}$ & $1.43 \mathrm{gh}$ & $26.77 \mathrm{~cd}$ & $1.87 \mathrm{c}$ & $5.13 b$ & $7.00 \mathrm{c}$ & $26.74 \mathrm{~h}$ \\
\hline $\mathrm{V}_{3} \mathrm{~S}_{2}$ & $4.33 \mathrm{f}$ & $3.43 f$ & $14.07 \mathrm{~g}$ & $2.05 f$ & $9.11 \mathrm{~g}$ & $32.57 \mathrm{e}-\mathrm{g}$ & $1.67 \mathrm{ef}$ & $25.48 \mathrm{f}-\mathrm{h}$ & $1.69 \mathrm{de}$ & $4.33 \mathrm{e}$ & $6.02 \mathrm{~g}$ & 28.00 e-g \\
\hline $\mathrm{V}_{3} \mathrm{~S}_{3}$ & $3.93 i$ & $2.93 \mathrm{~h}$ & $12.73 \mathrm{j}$ & $2.33 c$ & $8.76 \mathrm{~h}$ & $30.81 \mathrm{~h}$ & $1.74 \mathrm{~d}-\mathrm{f}$ & $24.21 \mathrm{ij}$ & $1.61 \mathrm{e}-\mathrm{h}$ & $3.73 \mathrm{~h}$ & $5.35 j$ & $30.24 c$ \\
\hline $\mathrm{V}_{3} \mathrm{~S}_{4}$ & 3.331 & 2.181 & $11.31 \mathrm{~m}$ & $2.66 \mathrm{~b}$ & $8.17 j$ & $27.23 \mathrm{kl}$ & $2.19 a b$ & $23.52 \mathrm{j}$ & $1.58 \mathrm{gh}$ & $3.11 \mathrm{k}$ & $4.69 \mathrm{~m}$ & $33.68 a$ \\
\hline $\mathrm{V}_{4} \mathrm{~S}_{1}$ & $4.26 \mathrm{~g}$ & $3.41 \mathrm{f}$ & $14.76 \mathrm{e}$ & $1.83 \mathrm{~h}$ & $9.48 \mathrm{e}$ & $33.28 \mathrm{de}$ & $1.68 \mathrm{ef}$ & $25.81 \mathrm{e}-\mathrm{g}$ & $1.87 \mathrm{c}$ & $4.77 c$ & $6.65 d$ & 28.25 ef \\
\hline $\mathrm{V}_{4} \mathrm{~S}_{2}$ & $3.90 \mathrm{i}$ & $2.80 i$ & $13.95 \mathrm{~g}$ & $2.16 \mathrm{~d}$ & $9.28 \mathrm{f}$ & $31.68 \mathrm{gh}$ & $1.81 \mathrm{c}-\mathrm{e}$ & $25.10 \mathrm{gh}$ & $1.63 e-h$ & $3.90 \mathrm{~g}$ & $5.53 i$ & $29.54 \mathrm{~cd}$ \\
\hline $\mathrm{V}_{4} \mathrm{~S}_{3}$ & $3.66 \mathrm{k}$ & $2.41 \mathrm{k}$ & $12.69 \mathrm{j}$ & $2.66 \mathrm{~b}$ & $9.00 \mathrm{~g}$ & $28.81 \mathrm{ij}$ & $1.97 \mathrm{c}$ & $23.57 \mathrm{j}$ & $1.55 \mathrm{hi}$ & $3.80 \mathrm{~h}$ & $5.35 \mathrm{j}$ & $28.97 \mathrm{de}$ \\
\hline $\mathrm{V}_{4} \mathrm{~S}_{4}$ & $3.16 \mathrm{~m}$ & $1.83 \mathrm{~m}$ & $11.89 I$ & $2.90 \mathrm{a}$ & $8.02 \mathrm{j}$ & 26.421 & $2.28 \mathrm{a}$ & $22.63 \mathrm{k}$ & $1.50 \mathrm{i}$ & $3.17 \mathrm{k}$ & $4.67 \mathrm{~m}$ & $32.11 b$ \\
\hline Sig. level & $* *$ & $* *$ & $* *$ & $* *$ & $* *$ & * & * & * & $* *$ & $* *$ & $* *$ & $* *$ \\
\hline CV (\%) & 0.8 & 1.08 & 0.74 & 1.5 & 1.08 & 2.01 & 7.45 & 1.83 & 1.82 & 1.1 & 0.88 & 2.19 \\
\hline
\end{tabular}

In a column, figures having same letter do not differ significantly as per DMRT. ${ }^{* *}=$ Significant at $1 \%$ level of probability, ${ }^{*}=$ Significant at $5 \%$ level of probability $\mathrm{V}_{1}$ : BARI Gom- 25, $\mathrm{V}_{2}$ : BARI Gom- 26, $\mathrm{V}_{3}$ : BARI Gom- 27 and $\mathrm{V}_{4}$ : Shatabdi; $\mathrm{S}_{1}: 15$ November, $\mathrm{S}_{2}: 30$ November, $\mathrm{S}_{3}: 15$ December, $\mathrm{S}_{4}: 30$ December.

\section{Conclusion}

The results of this investigation concluded that the highest plant population $\mathrm{m}^{-2}$ (58.17) and the highest plant height $(89.59 \mathrm{~cm}$ ) were recorded in 15 November sowing. BARI Gom 25 produced the highest plant population $\mathrm{m}^{-2}$ (50.33) and the highest plant height $(86.32 \mathrm{~cm})$ whereas the same trend was noted in the interaction of BARI Gom $25 \times 15$ November sowing. The lowest performance of these two parameters was recorded in the interaction of Shatabdi $\times 30$ December sowing. The highest grain yield $\left(2.18 \mathrm{t} \mathrm{ha}^{-1}\right)$ was found in the interaction of BARI Gom $25 \times 15$ November sowing as contributed by its highest number of effective tillers hill $^{-1}(4.73)$, the highest number of spikelets spike ${ }^{-1}$ (17.77), the highest number of grains spike ${ }^{-1}$ (37.89) and the highest 1000 -grain weight $(29.99 \mathrm{~g})$. The individual effect of the BARI Gom 25 and 15 November sowing on those parameters was also noticed as the highest. The lowest grain yield $\left(1.5 \mathrm{t} \mathrm{ha}^{-1}\right)$ was observed in the interaction of Shatabdi $\times 30$ December sowing due to the poor performance of the yield components of this treatment combination. The variety BARI Gom 25 and BARI Gom 26 both gave better yield when sown on 15 November. Consequently, BARI Gom 25 and BARI Gom 26 should be sown on 15 November rather than late sowing to obtain better performance and grain yield of wheat. Thus, the present study suggested that the varieties BARI Gom 25 and BARI Gom 26 when seeded on 15 November produced the highest yield under and usually dependent on the existing field conditions.
Open Access: This is open access article distributed under the terms of the Creative Commons Attribution License, which permits unrestricted use, distribution, and reproduction in any medium, provided the original author(s) and the source are credited.

\section{REFERENCES}

Akhtar, M., Cheema, M.S., Jamil, M. and Ali, L. (2006.) Effect of time of sowing on some important characters of wheat, Triticum aestivum genotypes. Journal of Agriculture Research, 44(4): 255-259.

Anonymous (1990). Lav Janak Pddhatite Utpadaner Upay (In Bangla). Bangladesh Krishi Gobeshona Institute, Gam Gobeshona Kendra, ashipur, Dinajpur, pp. 5.

Aslam, M., Hussain, M., Akhtar, M., Cheema, M.S. and Ali, L. (2003). Response of wheat varieties to sowing dates. Pakistan Journal of Agronomy, 2(4): 190-194.

Bajwa, M.A., Khan, N.I., Khan, S.H. and Khan, F.A. (1987). Effect of date of planting on grain yield of six wheat cultivars. Journal of Agriculture Research, 25 (1): 35- 43.

BARI, Bangladesh Agricultural Research Institute (1990). Means of Profitable Wheat Cultivation (A booklet in Bengali). Wheat Research Centre. Bangladesh Agricultural Research Institute, Nashipur, Dinajpur, pp. 1-11.

BBS, Bangladesh Bureau of Statistics (2013). Statistical Pocket Book of Bangladesh. Bureau of Statistics Division, Ministry of Planning Government of People's Republic of Bangladesh, pp. 211.

Chaudhry, M.H., Muhammad, S., Khan, G.S. and Khan, N.I. (1992). Optimum planting time of wheat (Triticum aestivum 
L.). Journal of Agriculture Research, 30(4): 447-452.

Gomez, K.A. and Gomez, A.A. (1984). Statistical Procedures for Agricultural Research. International Rice Research Institute Philippines. pp. 187-233.

Hossain, M.A. and Alam, N. (1986). Effect of date of sowing and seed rate on the yield of wheat (var. Kanchan) under irrigated condition. Bangladesh Society of Agronomy Conference, pp. 8.

Rahman, M.A., Mohabbatullah, M., Das, C.K., Sarker, U.K. and Alam, S.M.M. (2015). Sowing time and varietal performance of wheat at higher elevation in hill environment at Khagrachari. Bangladesh Journal of Agricultural Research, 40(4): 521528.

Saini, A.D. and Dadhwal, V.K. (1986). Influence of sowing date on grain growth duration and kernel size in wheat. Indian Journal of Agriculture Science, 56(4): 439-447.
Shah, W.A., Bakht J., Ullah, T., Khan, A.W., Zubair, M. and Khakwani, A.A. (2006). Effects of sowing dates on the yield and yield components of different wheat varieties. Journal of Agronomy, 5(1): 106-110.

Sultana, M.R., Alim, M.A., Hossain, M.B., Karmaker, S. and Islam, M.S. (2012). Effect of variety and weed management practices on yield and yield attributes of wheat. Journal of Environmental Science \& Natural Resources, 5(2): 91 - 96.

Vaishya, R.D. and Singh, V. (1981). Effect of seed rate, row spacing and nitrogen on yield and uptake of nitrogen in late sown wheat. Indian Journal of Agronomy, 26(1): 53--58.

Zia-ul-hassan M., Wahla A.J., Waqar, M.Q. and Ali, A. (2014). Influence of sowing date on the growth and grain yield performance of wheat varieties under rainfed condition. Science, Technology and Development, 33 (1): 22-25. 